\title{
Os missionários e os sobas: a experiência do padre Luiz Alfredo Kelling em Angola (séculos XIX e XX)
}

\author{
José Bento Rosa da Silva ${ }^{1}$.
}

Resumo: O artigo é sobre a presença dos Missionários do Espírito Santo em Angola nos séculos XIX e XX, a partir dos relatórios de Luiz Alfredo Kelling sacerdote, que, além de uma testemunha ocular, também mencionou outros relatórios missionários. Embora seja uma visão etnocêntrica, somos capazes de ver as formas de resistência dos colonizados, se fizemos uma leitura a contrapelo de tais relatos.

Palavras- chave: Missionários, colonização, angolanos.

Résumé: L'article porte sur la présence des Missionnaires de l'Esprit Saint en Angola dans le XIXe et XXe siècles, à partir des rapports de Luiz Alfredo Kelling prêtre qui, en plus d'un témoin oculaire, également mentionné d'autres rapports des missionnaires . Bien qu'il soit une vision ethnocentrique, nous sommes en mesure de voir les formes de résistance du colonisé , si nous avons fait une lecture à l'encontre de ces rapports.

Mots clés: Missionnaires, la colonisation. Angolais .

O padre Luiz Alfredo Kelling foi um dos membros da Missão do Espírito Santo que estiveram em Angola em fins do século XIX e início do XX. Seus relatos são nossas fontes ${ }^{2}$ para compreendermos em parte, sua experiência entre os cuamatas desde o século XIX:

[...] altos, bem formados, desembaraçados, pouco habituados a baixar os olhos $^{3}$, ladrões, é verdade, mas dizendo que o 'cunhama coisas pequenas não as rouba', altivo, portanto, até nos vícios. Se folhearmos a história, não precisamos de ir longe para os encontrar defrontando-se com os nossos exércitos $^{4}$ nem necessitamos de interrogar muitos ganguelas para vermos o terror que este povo lhes inspira[... $]^{5}$

Os cunhamas, subdivisão da etnia Ovambo, do sudoeste africano não foi um páreo

1 Professor Adjunto na Universidade Federal De Pernambuco UFPE, vinculado ao Centro de Estudos Africanos da Universidade do Porto (CEAUP) e ao Núcleo De Estudos Das Relações Étnicas E Raciais da Universidade Federal de Santa Catarina-(NUER). E-mail: negrobento@hotmail.com .

2 São fontes secundárias disponíveis no site eletrônico:http://memoriaafrica.ua.pt/introduction/tabid/83/language/pt-

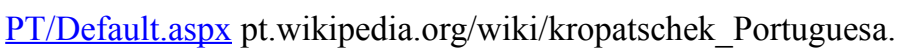

3 O grifo é nosso.

4 O grifo é nosso.

5 Boletim Geral das Colônias Vol. II, n.18. Portugal. Agência Geral das Colônias, 1926, p.20. 
fácil para os colonizadores da região ${ }^{6}$, como se verá nos relatos dos missionários, embora o padre Kelling dissera que seu interesse não era falar de guerras, tampouco de diplomacia, mas tão somente das missões, e que para isso recorreria a relatos anteriores, como o do padre Duparquet, que remonta os anos de 1879 .

\section{Mapa Etnográfico dos povos de Angola}

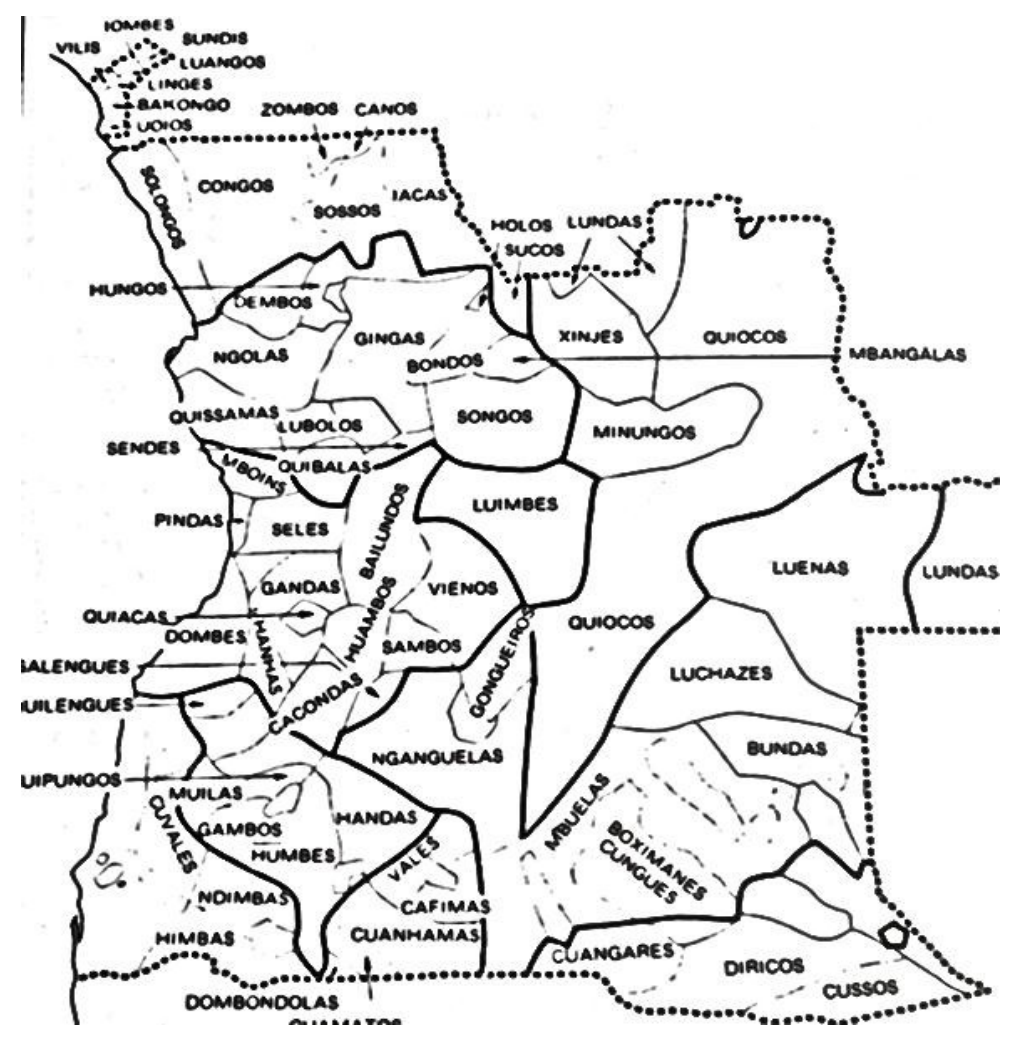

Fonte: PÉLISSIER, René. História das Campanhas de Angola. Lisboa: Editorial Estampa, 2013, 3ª ed. (Mapa IV Anexos)

Consultando as anotações de Duparquet, o missionário constata a presença de comerciantes na região, que segundo ele teriam ajudado no processo de catequização. Cita por exemplo Axel Erikson, proprietário de uma casa comercial sueca, acrescentando que era 'o homem de certo mais influente nesta região', e para provar a importância de Erikson como colaborador nas missões, reproduz Duparquet: "Mostrou-se de uma tal amabilidade, foram tais e tantos os serviços que nos prestou que sempre as missões lhe colocaram o nome entre os mais insignes benfeitores"7.

Das anotações de Duparquet, o padre Kelling destaca a receptividade que este tivera

6 "[Os] ovambos de além Cunene, pastores ariscos que durante muito tempo fizeram impertinentes razias que tornaram o sul de Angola no pesadelo do exército português até 1916[...] "In. PÉLISSIER, René. História Das Campanhas De Angola.Vo.I. Lisboa: Editorial Estampa, 2013,3a .Ed.,p.23.

7 Idem., p. 21. 
no momento em que chegara em terras africanas; fala também das dificuldades encontradas e resistências ao projeto missionário católico,atribuindo esta resistência às missões protestantes ali instaladas ou em instalação:

[...] Todo viajante que chega a estas terras tem de esperar, na fronteira, licença do rei para penetrar até ele. Como Chinona, irmã do rei, morasse perto, fui-lhe fazer uma visita. Mostrou-se de uma amabilidade extrema e mais de uma vez me ofereceu cerveja indígena. Num dia chegou-me mesmo a convidar para jantar. Aceitei. [...] Em dezembro seguinte temos o padre Duparquet de volta, mas que de mudanças não veio encontrar na sua recente missão de Omaruru! Desenvolvera-se e muito, a escola, afluíam os catecumenatos, mas os protestantes, tantas vezes pintaram ao pretinho os recém-chegados como aventureiros, que lhe vinha a roubar a pouca liberdade,deixada pela Inglaterra, que, depois de terem sofrido vários insultos, tiveram os católicos de se retirar para Walwich-Bay [...]. ${ }^{8}$

Embora os missionários católicos atribuíssem às resistências dos africanos aos protestantes, os relatos reproduzidos por Kelling dos precursores padre Duparquet e outros, apontam para outras questões: os missionários conseguiam em dado momento convencer algumas autoridades locais a conceder licença para instalarem missões, mas quando estes faleciam, as lideranças mais velhas, que a nosso ver não foram consultadas, reagiam ao projeto evangelizador, como se depreende do relato abaixo:

[...] As notícias que de lá lhe vinham não eram de modo nenhum para o tranqüilizar. Havia morrido o soba Chipandeca e sucedera-lhe, como é de lei nestas terras, um seu sobrinho, chamado Nambadi. Este, que não contava mais de 18 a 20 anos, aspirava à instrução, e , vendo que os missionários católicos tardavam, dirigira-se um pedido aos luteranos de Ondonga. O padre Duparquet, pouco habituado a demoras, mete-se á jornada, chega ao Cuanhama, apresenta-se a Nambadi e declara-lhe que vinha fundar uma missão, como combinara, havia quatro anos, como o falecido Chipandeca. Recebido de braços abertos, empreende as construções e já as principais estavam terminadas[...] Nambadi estava encantado com os missionários e este não estavam menos entusiasmado com o rei do Cuanhama[...] Como é fácil de adivinhar, mesmo sem ser grande entendido em questões de África, os velhos viam na missão e no incremento, que ela tomava, a ruína da sua autoridade própria[... $]^{9}$

O jovem soba vem a falecer no final do primeiro semestre do ano de 1885 , o missionário sugere que ele teria sido envenenado pelos mais velhos que não concordavam com a abertura para o catolicismo. Com a morte do soba vieram os reveses para os missionários:

[...] Nambadi está doente, Nambadi está à morte! Na flor da idade! Aos

8 Idem., Ibidem., p.25-26

9 Idem., Ibidem, p.27 
vinte e dois anos!

É bem possível que alguém o ajudasse... a morrer.

Mal Nambadi fechara os olhos, deu-se a desordem, que sucede cada vez que falece um soba[...] Os velhos, como era de prever, aproveitaram tão azada ocasião para atacar os missionários e nos princípios de junho trucidaram-nos a todos e pilharam a missão.

Os móveis, a comida, até o zinco das casa, tudo foi dividido entre os assaltantes.Que de esperanças perdidas de um momento para outro! Que de sonhos dissipados! E que de vidas preciosas ceifadas, quando tanto delas se precisava! Reduzida a um montão de cinzas fumegantes aquela missão ainda ontem o orgulho do bom fundador! ${ }^{10}$

No relato do missionário, a morte do soba desencadeou uma série de transtornos às missões católicas, segundo ele, uma desordem. Acrescenta ainda que tal desordem era comum em sociedades africanas, quando da morte do soberano: [...]Mal Nambadi fechara os olhos, deu-se a desordem, que sucede cada vez que falece um soba. Há uma lei nestas terras, em virtude da qual, durante o interregno, se permitem todos os crimes, sem que os culpados possam mais tarde ser chamados à responsabilidade $[\ldots]^{11}$. Na verdade tratava-se não de uma desordem, mas de um rito de passagem: com a morte do soba e o processo de sucessão há tensões no seio da sociedade, em virtude da vacância de poder, pois que aos sobas são creditados poderes sobrenaturais ${ }^{12}$. Para os Mossi, o chefe é o sustentáculo do tempo coletivo, conforme nos mostra Boubou e Ki-Zerbo:

Mwami está presente:o povo vive. O Mwami está ausente: o povo morre.A morte do rei constitui uma ruptura do tempo que paralisa as atividades, a ordem social,toda expressão da vida, desde o riso até a agricultura e a união sexual dos animais e das pessoas. $\mathrm{O}$ interregno constitui um parêntesis no tempo. Apenas o advento de um novo rei recria o tempo social que se reanima novamente ${ }^{13}$.

Após o insucesso, o padre Duparquet, que escapou com vida, em virtude de encontrarse em Huila, retirou-se para o Congo francês, sendo substituído pelo Schaller. Segundo Keling, por esta época, por volta de 1892, o soba do Cuanhama era Eyulu, 'um homem que se sabia impor', e

10 Idem., Ibidem.,p.28.

11 Idem., Ibidem., p. 28.

12 Sobre esta questão. Ver. ADLER, Alfred. Fazedores De Chuva, Fazedores De Ordem: reflexão sobre as relações da magia e do poder na África Negra. In. CLASTRES, Pierre (Org.) Guerra, Religião, Poder. Lisboa: Ed. 70,1977.

A descrição de Antônio Pacheco em Moçambique do século XIX é também ilustrativa: “ [...]Por morte de qualquer mambo, e durante o oitaviário concorre todo o povo do distrito, o mais indecentemente vestido que pode imaginarse a chorar na povoação a perda ingente que acaba de sofrer, praticando ao mesmo tempo toda a casta de desatinos,isto é, matando e ferindo e roubando toda a pessoa que passar pelo território onde sucedeu o óbito antes de ser aclamado um novo príncipe".Albino Pacheco.Viagem de Tete a Zumbo(1861-1862).Apud. M'BOKOLO, Elikia. África Negra: História E Civilizações. Tomo I.Salvador: Edufba/ SP: Casa das Áfricas,2009,p.180

13 HAMA, Boubou e KI-ZERBO, J. Lugar da história na sociedade africana. In.KI-ZERBO,J.(org) História geral Da África Vol. I - Metodologia e pré-história da África.Paris: Unesco/Brasília:Ministério da Educação, 2010, 2a . Ed. rev. 
que recebera bem os missionários.

Em 1903, dezoito anos depois do malogro de Duparquet, a missão voltou a ser 'ameaçada' em virtude novamente do falecimento da soberana, conforme Kelling:

"[...] Em junho de 1903 morre inesperadamente a rainha Ddatioli.Podia-nos, ser fatal, como fora ode Nambadi, dezoito anos;mas apareceu o próprio soba Eyulu para nos proteger.

À rainha Ddatioli, no centro de Matadiva, sucedera o seu filho Hamálua, o que, embora contasse apenas 20 anos de idade, manifestava maus instintos ,devido principalmente à maligna influência dos seus conselheiros, que eram os homens velhacos do Cuahama. Como já no tempo de Nambadi, os velhos(que entre os cuahamas se chamam lengas), eram inimigos figadais da missão. Sentindo-se mais à vontade depois da morte da rainha, começaram a molestar os missionários.Em breve a situação se tornou insuportável. Era um ódio, um rancor que eles tinham à missão, que aquilo parecia coisa diabólica. Sempre e por toda parte achavam boa a ocasião azada para insultar os padres e atacar os educandos. Por duas vezes chegou a haver tiros de espingarda. Como era natural os nossos defendiamse e duma dessas refregas saíram alguns dos nossos feridos e do lado deles um morto. É óbvio que nestas condições não podíamos continuar e por isso buscamos lugar onde houvesse sossego e pudéssemos dispor de térreos para os catecúmenos $[\ldots]^{\prime \prime 14}$.

Do relato de Kelling, depreende-se a função dos mais velhos, qual seja, do conselho de anciãos, cuja uma das funções era o aconselhamento ao rei. De certa forma eles eram os guardiões da memória, das tradições dos antepassados; as inovações na comunidade tinham que passar necessariamente por eles, não bastava, ao que nos parece, a 'autoridade ' do rei. Ou dizendo de outra forma, o rei não tinha todos os poderes na comunidade. Neste tipo de organização social, o chefe tem mais deveres do que poderes, como nos adverte Pierre Clastres, uma sociedade onde a distinção é mais função do que poder ${ }^{15}$.

Cabia, portanto, aos velhos, a permissão ou não, para implantação das práticas religiosas cristãs nas aldeias africanas. No caso de recusa, os missionários os viam como inimigos figadais ou possuídos pelo diabo. Aliás, no Brasil também ocorreu esta interpretação por parte dos catequistas, como mostram as pesquisas de Laura de Mello e Souza acerca do Brasil Colonial ${ }^{16}$. A resistência à religião, era, portanto, uma forma de resistência ao próprio colonizador.

E mais, ao que o missionário chama de antipatia dos velhos africanos em relação ao cristianismo, era na verdade o zelo pela comunidade, como acontecera em outros momentos

14 Boletim Geral das Colônias. Vol. II, n.18. Portugal: Agência Geral das Colônias,1926,p. 29-30.

15 Sobre esta questão. Ver. CLASTRES, Pierre. A Sociedade Contra O Estado.

16 Estamos nos referindo à obra: SOUZA, Laura de Mello e. O Diabo E A Terra De Santa Cruz: Feitiçaria e religiosidade popular no Brasil Colonial. SP: Companhia das Letras, 1986. 
conforme tivemos a oportunidade de observar em outros relatórios dos colonizadores ${ }^{17}$.

Os missionários após este infortúnio dirigiram-se para a região norte e com a permissão do soba Eyulu ali se instaram, depois de algumas negociações. O religioso adverte aos que porventura pudessem recriminá-los pelo fato de ter que pedir permissão a um 'potentado negro', ao que respondeu com um dito popular lusitano:

[...] Talvez neste ponto alguém se admire de pedirmos licença ao potentado negro, mas lembre-se que estamos em 1900 e pico e que o Cuanhama não estava ainda ocupado pelas autoridades portugueses.O leitor já esteve em relação com os habitantes de Trás dos Montes?Sabem, portanto, o que eles dizem? 'Para aquém de Marão, mandam os que cá estão!'[... $]^{18}$

O que quis o autor dizer é que estavam limitados às autoridades locais, ainda que estes fossem os negros, deveriam submeter-se a eles, mesmo na condição de 'superiores', posto que fossem eles os donos da terra... Ao menos até que chegassem as tropas lusas com os seus administradores. Parafraseando o dito dos habitantes lusos de Trás dos Montes, diríamos: "manda quem pode, obedece quem tem juízo!” E mais, o autor estava consciente da possibilidade de os leitores posteriores tecerem críticas ao comportamento dos colonizadores, ou fato de submeterem-se ao potentado negro, tendo de pedir licença para se instalarem. Ele justifica-se: eram outros tempos!

Ainda que o soba Eyulu houvesse selado pacto de amizade e proteção com os missionários católicos portugueses, as coisas não estavam tão seguras como se imaginava. Isso, em nosso ver, mostra os limites da autoridade de Eyulu na região. No ano de 1903 o soba vizinho, Cavongélua agiu contra a presença do alienígena em território africano. Nesta ação nos faz pensar também no conceito de território e territorialidade em determinadas sociedades, qual seja, o território como lugar residencial e territorialidade como o espaço pelo qual a comunidade circula,

170 capitão A.A.da Silva Guardado, um dos responsáveis pela campanha de vacinação na mesma região em 1897, fez o seguinte relato: "[...] um grande ajuntamento de pretos, quase todos velhos. No alto da cabeça apresentavam pequenos barretes feitos de fibra de imbondeiro - boabab - à laia de solidéus cardinálicos, (semelhantes a solidéus dos cardeais)os quais constituem entre o gentio um símbolo de autoridade. Informou-me o intérprete que estes venerandos personagens eram os séculos ou sobetas da terra, representantes do soba nas povoações mais importantes, a que chamam t'chilongos.Estavam reunidos em magna assembléiae, sob a presidência do soba,discutiam acaloradamente. Tratava-se, em face do que[...]

Depois de muito debatido o problema em causa,depois de os oradores, em largos gestos de eloqüência cafreal, terem exposto os seus pontos de, muito apreciados pelos circunstantes que aplaudiram com entusiasmo, terminou a sessão[...]

Pouco depois o soba veio ter comigo e começou um longo e substancioso discurso - os negros em geral, são grandes oradores $-[\ldots]$ Resumindo: que não podia cumprir o que na véspera combinara com o chefe e os oficiais, porque o seu povo, representado pelos séculos que eu tinha visto ali reunidos, se opunha a que o gado fosse vacinado... que esse gado era pertença ou bens do sobado e não ele, que apenas podia usufruir do seu rendimento[...]" In. GUARDADO, A. A. da Silva. Cadernos Coloniais, n.34. O Massacre dos dragões do Conde de Almoster Lisboa: Editorial Cosmos, 1939,p.10-11.

18 Boletim Geral das Colônias. Vol. II, n.18. Portugal: Agência Geral das Colônias, 1926, p 30. 
para além do espaço residencial. Neste sentido, o soba Cavongélua, estava defendendo o direito à territorialidade:

[...] Combinamos assim as coisas, foi nos últimos dias de novembro de 1903, o padre Génie, mais o irmão Dionísio, começar os trabalhos no novo local.

Quem não ficou nada contente com a nossa vinda para este lugar, foi o soba do Evale, o famoso Cavongélua, que tinha pouca vontade de nos ver no caminho por onde passavam os seus, quando iam assaltar as libatas. Resolveu, por isso, declarar-se nosso inimigo e determinou enviar uma guerra contra a missão, a ver se se desistia da empresa $[\ldots]^{19}$.

O embate ocorrido a dois de dezembro do ano de 1903 colheu a vida do irmão Dionísio, o que fez o padre Génie retirar-se para Matadiva, onde estava o padre Gaillard... Os negros estavam mesmo com o 'diabo no corpo', talvez imaginassem os missionários, enquanto esperavam a expedição militar que estava prestes a chegar no Cuahama, mas esta, devido ao mal tempo, só chegou em setembro do no seguinte. Neste meio tempo, os missionários ficaram 'peregrinando' de região a região, buscando um lugar seguro para implantar as missões.

Os tempos ' estavam mesmo bicudos' para os missionários. Ou as força do mal estavam vencendo as forças do bem? Quando finalmente chegou a expedição militar, por volta de vinte de setembro de 1904, falece o soba Eyulu, suposto aliado dos portugueses:

[...] Morre quase subitamente o soba Eyulu,nosso amigo. Como fácil é compreender, esta morte deixou-nos alarmados. Como uma rapidez inconcebível, onde não há telégrafo nem telefone, começaram a circular os mais aterradores boatos: que íamos ser atacados e trucidados e as nossas casas saqueadas.

Como era de praxe, mandamos os pêsames aos sobas Nande e Hamálua, irmãos do falecido.

Em Ndjiva, onde fora a imbala (aldeia) de Eyulu, congregou-se uma enorme multidão de povo e o herdeiro teve de ouvir durante alguns dias os avisos, conselhos, queixas e representações de quantos quiseram falar. Declaram-se todos contra os brancos: era urgente matá-los, ou pelo menos expulsá-los. Afirmavam mesmo alguns que a causa da morte de Eyulun eram os padres. Felizmente Nande não se deixou influenciar e não consentiu nunca que se fizesse o menor mal á missão $[\ldots]^{20}$.

Como vimos anteriormente, os momentos de sucessão eram os momentos de maior instabilidade na comunidade, sobretudo para os colonizadores, como se depreende da leitura acima. E mais, com a morte do soberano, os acordos anteriores precisariam ser refeitos ou mesmo

19 Idem., p; 31.

20 Idem., Ibidem., p.32. 
revogados. A assembléia era soberana e demorava alguns dias, talvez longos demais ao olhar do estrangeiro...

Vieram os acontecimentos do ano de 1904, descritos por Manoel Francisco Contreiras Júnior como $\mathrm{O}$ Massacre do Cunene ${ }^{21}$; mas que segundo o missionário, as missões foram preservadas, e sugere que o ' desastre' não fora maior para tropas lusas, graças a presença dos missionários $^{22}$. Continua descrevendo o crescimento das missões em meio a instabilidade reinante. As forças do bem pareciam jogar a favor, sobretudo com a astúcia dos padres Lecomte e Génie, que 'aconselhavam' os indígenas a manterem-se ao lado dos portugueses.

Diante da presença do estrangeiro, seja militar ou religioso, ou civil, por vezes os ‘ indígenas' uniam-se, visando vencer o inimigo comum, mostrando que nem sempre as diferenças étnicas eram sinônimas de divisão e dispersão, como sugerem algumas interpretações quando de se fala da diversidade étnica e cultural no continente africano, seja no passado ou no presente.

As expedições lusitanas e as resistências indígenas foram retratadas pelo missionário, embora no início de seu relatório havia dito que a finalidade do mesmo era tão somente os temas relativos às missões, procurava a ' tal objetividade' tão em voga na época. Vejamos o que ele nos diz acerca dos conturbados dias de setembro de 1904 :

[...] Encetaram-se novas operações do Cuamatui. A princípio zombavam os cuanhamas do esforço tentado pelo governo para submeter os aguerridos cuamatuis e faziam notar que estes eram da mesma família que os hereros, que tanto faziam suar os alemães, ali ao lado. Não acreditavam na possibilidade da vitória dos brancos e mesmo um certo número deles, capitaneados pelos ' lengás' Calola e Makili, foram juntar aos cuamatuis[...] Os padres Lecomte e Génie foram visitar os sobas Nande e Hamálua e aconselharam-nos a que se manifestassem francamente pelo governo português, mostrando-lhes que, se por acaso esta expedição fosse mal sucedida, viria outra, e depois outra. Que o exemplo dos hereros, não colhia, porque, se os alemães não podiam com eles, não era costume de Portugal ter na África dois revezes seguidos[... $]^{23}$.

Os hereros ${ }^{24}$, do vizinho território colonizado pelos alemães, eram motivos de inspiração para estes grupos revoltosos, que inclusive fazia-se de parentes dos mesmos. E mais, zombavam dos portugueses, uma vez que seus parentes davam 'dor de cabeça' aos alemães, e os

21 CONTREIRAS JÚNIOR, Manuel Francisco. Cadernos Coloniais, n.44 (O Massacre Do Cunene ). Lisboa: Editorial Cosmos, 1937.

22 "[...[ Deu-se o desastre do Cuamatue. Situação crítica. A missão conservou-se sossegada e trabalhava, como se nada fosse.Todos os cuanhamas sabiam que ela fora para ali por instigações do governo e era por este sustentada. Foi devido a ter ficado a missão que se mantiveram boas as relações entre cuanhamas e o governo português[...]" In. Boletim Geral das Colônias.Vol. II, n.18,Portugal: Agência Geral das Colônias, 1926,p33.

23 Boletim Geral das Colônias.Vol. II, n.18. Portugal: Agência Geral das Colônias, 1926, p34.

24 “Grupo étnico do sudoeste africano. Distribuiu-se pelo planalto árido da Namíbia, sudoeste de Angola e Norte da África do Sul. Compreende os subgrupos Dimbas, Chimbas, Chavicuas, Cuanhocas, Cuvales e Nguendelengos” In. LOPES,Nei. Enciclopédia Brasileira Da diáspora Africana. São Paulo: Selo Negro, 2004, p.326. 
portugueses sabiam disso. Mas o missionário fez ver às lideranças, sobretudo aos sobas Nande e Hamálua, que com os portugueses as coisas seriam diferentes, pois que 'não era costume dos portugueses ter na África dois revezes seguidos!' dando a entender que eram mais organizados e mais poderosos do que os vizinhos alemães ao sudoeste da África ${ }^{25}$.

O missionário atribui aos 'lengás' a tarefa de semear a cizânia em meio aos demais. $\mathrm{Na}$ verdade a categoria lengá eles haviam criado para identificar os mais velhos, os anciãos, os conselheiros, que como vimos acima, eram os que advertiam as autoridades quando, - sobretudo os mais jovens-, faziam acordos com o colonizador. Mas porque denominá-los de lengá? Ora, porque é uma palavra derivada de lenga, do umbundo, que significa safar-se ${ }^{26} . \mathrm{E}$ isto os conselheiros sabiam fazer bem, safarem-se dos colonizadores.

Em que medida os conselhos dos missionários foram acatados pelas lideranças? Em nosso ver, eles 'faziam duplo jogo', ao que levou o missionário a pensar que ele não tivesse as qualidades de um bom líder, aos moldes ocidentais. Isto dificultava as atividades dos missionários:

[...] Mas Nande, que para ser grande rei só lhe faltava a decisão, flutuava sempre, indeciso, sem tomar uma resolução. Não queria combater os portugueses, mas também não se desejava indispor com os cuamatuis; deste modo ficou a missão exposta a cada instante às violências dalguns fanáticos, que à missão atribuíam a ocupação do Cuamatui[...]Só quem por viveu pode avaliar os transtornos, prejuízos e estragos ocasionados pelas contínuas correrias das guerrilhas cuanhama na enorme região de Cassinga, Dongo, Cubando, Galangue, chegando de uma vez a aprisionar três soldados, a quem tiraram as armas, os vestidos todos, remetidos em seguida para a fortaleza[... $]^{27}$.

O padre Kelling disse que quando esteve nesta região pela vez primeira, por volta de 1910, o quadro era desolador: o rebanho havia desaparecido, mal se podia cultivar os campos, o medo era constante, a vida sempre em risco... Não é difícil imaginar o espírito da população local que, desde a chegada do colonizador via seu mundo virar de cabeça para baixo, ou para usar uma expressão do nigeriano Chinua Achebe, "o mundo se despedaçar"28.

Do relato de kelling, depreende-se que o soba Nande teve uma relação amistosa com a missão católica no Cuamate, mas que com a morte deste em 1911 as coisas ficariam novamente incertas, uma vez que seu sucessor Mandume era de outro temperamento, além da influência que

25 Os alemães colonizavam nesta época, a região que hoje equivale à Namíbia.

26 LOPES, Nei.Novo Dicionário Banto Do Brasil.Rio de Janeiro: Ed.Pallas, 2003,p.126.

27 Boletim Geral das Colônias.Vol. II, n.18. Portugal: Agência Geral das Colônias, 1926, p35.

28 Sobre o impacto da cultura ocidental em África. Ver. ACHABE, Chinua. O Mundo Se Despedaça. São Paulo: Ática, 1983. 
havia recebido dos vizinhos alemães, que além da má influência, invadia território português.

Quanto ao soba Mandume, João Francisco e Souza ${ }^{29}$, escreveria sobre o mesmo no ano de 1939, nos Cadernos Coloniais, ao rememorar os 'grandes feitos' dos antepassados para a grandeza das terras portuguesas de além mar. Pois bem, mas o que dissera Kelling acerca de Mandume? Dissera que ele era "um germanófilo dos quatro costado, por ter sido educado numa missão alemã protestante". Noutro momento descreve a ação de Mandume contra a missão “[...] mandou Mandume ocupar a fronteira norte do Cuanhama e destruir todas as casas da missão, roubando tudo o que havia: rancho, portas, janelas e até algumas alfaias, que na igreja tinham ficado, e dizendo que fora iludido pelos padres, mas que se havia de vingar [...]"30.

A partir do ano de 1914, com a eclosão da primeira grande guerra, a situação piorou para os missionários, as disputas nas fronteiras com os alemães tornaram-se intensivas, somadas as 'rebeldias' dos cuanhamas, mesmos as guarnições enviadas para sufocar as revoltas eram insuficientes, como fica patente na narrativa abaixo, quando a missão foi acordada sem mesmo ter tido o tempo do descanso necessário para enfrentar as atribulações do dia seguinte:

[...] Nem tempo tivemos de fechar os olhos, que na colina da missão ouvimos um tropel de gente. Entre o ladrar furioso dos cães, distinguimos vozes que nos chamam, gemidos dolorosos e uma ou outra luz no meio das trevas... A que seria devido tanta bulha? Saímos. era a guarnição do Evale, toda ali à porta da missão.

-Senhor padre, dá licença?

- Ora essa! Entrem. Estejam à vontade. Então que há? Que resolução foi esta?Acabava de enviar o nosso carro à fronteira... Mas que temos?

- Ora!Ora... Que há de ser? Ordem de retirada, ataque dos evales, mortos, feridos. Por um pouco não chegava ninguém...

Ouviam-se ao mesmo tempo os gemidos dos feridos, as disputas dos que os conduziam, em macas improvisadas, feitas de cobertores. Aqui viasse um pobre sargento, de 22 anos de idade, com os intestinos perfurados por uma bala e na espinha dorsal uma larga ferida profunda devida a uma zagaia; ali um infeliz artilheiro com a cara esfolada, as mãos e os braços cheios de sangue. Este queixa-se de que tem uma bala na coxa, aquele no braço, aquel'outro; ao todo 22 feridos.

Juntamente com estes, vinham-nos, além do comandante do forte Evale, 3 sargentos, 10 soldados brancos, 80 soldados pretos, 2 comerciantes, os srs. Vale e Nicolau Ferreira da Conceição, mais aproximadamente 60 pretos com os filhinhos[... $]^{31}$.

Segundo Kelling, já havia sido dada a resolução do governador geral da colônia que deveriam retirar-se da área em litígio, e dirigirem para lugar mais seguro, para o Lubango, para isso

29 SOUZA, João Francisco de. Infantaria 17 em África. Cadernos Coloniais, n. 57. Lisboa: Editorial Cosmos, 1939.

30 Boletim Geral das Colônias. Vol. II, n.18. Portugal: Agência Geral das Colônias, 1926, p38.

31 Boletim Geral das Colônias. Vol. III,n.19.Portugal: Agência Geral das Colônias,1927,p.139-140. 
fora enviada a expedição que malogrou a meio caminho. Os cuanhamas descobriram o intento e atacaram antes. Como descobriram o planejado? Como as informações 'vazaram' para o inimigo? Na opinião de kelling devido à falta de moral: "os indígenas haviam sido avisados pelas suas filhas, mulheres dos soldados ou companheiras dos europeus". A relação entre soldados europeus possuíam indígenas como companheiras, não se sabendo por quais meios; estas companhias possibilitavam ao inimigo saber das ações dos lusos; os soldados auxiliares negros não pareciam de confiança, pois que suas mulheres, também podiam ‘dar com a língua nos dentes'...

Notamos a existência de uma rede de informações em meio aos 'indígenas' que possibilitavam agir antes mesmo das expedições lusas, ou surpreender aquela que se achava em lugar seguro. Aqui podemos tomar emprestado o dito popular que diz: 'as paredes têm ouvidos!' No caso específico não eram as paredes, mas os arbustos. Estas redes também por vezes ajudavam os lusos, uma vez que havia os sobas aliados, que ficavam sabendo das notícias por 'este correio sem selo' e antecipavam o plano dos 'indígenas inimigos' dos lusos: “o mesmo aviso fora dado a um lengá muito importante, irmão do soba Eyangelua, que, como já se disse, aceitara a ocupação pacificada sua terra".

Kelling também deixou evidente que havia a participação de expedições alemãs incentivando os 'indígenas'. Não ignoramos isso, afinal estava em tempos de guerra, ocasião propícia para que os 'indígenas' pudessem 'jogar' hora com os portugueses, hora com os alemães, belgas, ingleses... Enfim usavam de táticas e estratégias que melhor lhe convinham a cada tempo.Um tema muito caro a Michel de Certeau... ${ }^{32}$

$\mathrm{Na}$ verdade os preparativos para saírem da região já estavam praticamente quando aconteceu o ataque de forma calculada pelos 'indígenas', como se pode concluir da narrativa abaixo:

[...] Em menos de meia hora estava tudo pronto para marchar. Oficiais, soldados, comerciantes dirigiam-se a toda pressa para a missão, que estava a quarenta quilômetros.

No princípio tudo parecia favorecer esta retirada. Mas duas horas mais tarde foram cercados por Muatilefu e os seus partidários. E foi assim que, perseguidos durante bons 35 quilômetros, eles chegaram à missão debaixo de uma chuva de balas, tendo deixado no caminho 12 mortos, entre os quais um comerciante de nome Barros[... $]^{33}$.

Continua da descrição mostrando em que condições chegaram nas missões, sem nada, tiveram que abandonar tudo: víveres, munições, medicamentos... E mais, haviam andado por cerca 
de dez horas... Pretendiam ir para Lubango, distante ainda a quinze ou vinte dias de distância. Mesmo sem condições, diz o missionário, a missão colocou à disposição dos vitimados o que se tinha.

Aquartelados na missão, aguardava-se o pior, até que uma notícia acalentou relativamente a todos: os inimigos haviam se retirado por lhes faltar munição. Seria verdade ou mais um boato que circulava, não se sabendo bem de onde tivera origem? Não demorou até que o soba Muatilefu cercou a missão exigindo que os missionários entregassem o chefe militar, os soldados e suas armas. Sem que o chefe ficasse sabendo, os missionários negociaram com o soba, argumentando que ali estavam os refugiados, doentes e feridos. Convenceram o soba, com o argumento que, no passado quando ele havia se refugiado, também não fora entregue aos chefes militares. Portanto, tratava-se de uma ética, ao que o missionário denominou 'argumento ad hominem'. Se assim foi, denota que os 'indígenas' não tão 'selvagens', quanto deles se falava...

Abrimos um parêntesis aqui para dizer que kelling menciona que os soldados não tinham ânimo para saírem da missão, apontando que ela fora mesmo um lugar de refúgio durante o dia, e que a noite seria uma oportunidade de seguirem em frente, mas:

[...] Declina, no entanto, o dia e chega a noite em que a guarnição se havia de retirar para Cassinga. O chefe não tomava uma resolução. Os homens, desmoralizados, recusavam partir:ou ficar na missão ou serem acompanhados por nós.

O nosso posto não podíamos abandonar. Afinal, alvitamos um meio termo, que foi bem aceito: iríamos com os soldados alguns quilômetros e depois eles seguiriam em companhia do irmão Silvano, levando uma escolta, composta de rapazes da missão, até Cassinga[...]"34

Assim foi feito, a guarnição foi 'escoltada' pelos religiosos e os membros da missão. Que dura ironia o destino estava pregando aos militares! Caso houvesse dúvidas sobre a utilidade das missões em terras africanas, esta ação por si só justificaria tal presença. Aliás, o missionário já havia dito com todas as letras que, não fosse à presença missionária na região, os revezes sofridos pelas expedições daquele período teriam sido bem maiores ${ }^{35}$.

Mal retornaram à missão e se preparavam para dormir quando um pequeno cuanhama veio dizer que a expedição seus guardas costas haviam retornados, em virtude da suspeita de uma cilada. Pernoitaram nas missões.

No dia seguinte verificou-se que não havia nada de extraordinário, com certeza fora fruto da imaginação e do medo que tais circunstâncias proporcionam. Para garantia da viagem,

34 Idem., Ibidem.,p.142.

35 Ver a nota n. 20 deste escrito. 
padre Devis decidiu acompanhá-los até Cassinga. Aumentado com certeza o constrangimento dos militares, ao menos nas palavras de kelling:

[...]Agora o próprio padre Devis, que os vai conduzir a Cassinga.

Era a salvação destes pobres militares, abatidos e desmoralizados; mas era um grande sacrifício para o padre. Foi tudo regulado no meio dos mais acalorados agradecimentos [...] Às11 horas da noite do dia 24 tomaram de novo os soldados o caminho de Cassinga $[\ldots]^{36}$.

Era véspera de natal, o missionário não deixou de relacionar o sucesso da empreitada do padre Devis com o nascimento de Jesus Cristo, em meio a descrição da celebração que foi realizada na missão, acrescentando que os motivos de tantas guerras naquela época era justamente devido á falta de fé. Fé que não faltou ao padre Devis, com certeza! E mais, kelling disse que os cuanhama perseguiram a expedição e que, só não lhes fizeram mal algum dado á presença do padre Devis.

Festejavam o dia do natal quando chegou a notícia que outra guarnição fora atacada pelos cuanhamas e por gente de Muatilefu. O que parecia um boato foi confirmado em seguida:

[...] Espalhou-se o boato, infelizmente confirmado depois, de que quase toso tinham sido trucidados, dois brancos (entre os quais o sargento Reis) haviam sido entregues ao rei do Cuahnhama e que Muatilefu se apoderara do tenente Encarnação, comandante do forte Cafima, para fazer um sacrifício a fim de aplacar os manes(os espíritos) de seu irmão Eyangelna.

Chegavam-nos ao mesmo tempo as mais desastrosas notícias da retirada de todos os brancos do Humbe, Donguena, Cafú, Chiteve e Munongue, e, como resultado desta debandada, a revolta de todos o indígenas, pilhando, roubando tudo o que havia pertencido aos brancos. Era simplesmente assombroso e inacreditável $[\ldots]^{\prime 37}$.

A sociedade local era hierarquizada haviam os chefes locais, que aos que nos parece estavam subjugados a uma autoridade maior; no caso específico a autoridade maior era o Mandume, e Muatilefu um dos seus inferiores. Conhecendo esta realidade, pode os missionários, de certa forma, evitarem maiores males, como se verá em seguida.

No dia 28 do mesmo mês de dezembro Muatilefu volta à missão acompanhado de 500 'indígenas' armados exigindo que os missionários entregassem o chefe militar e os soldados. Depois de implorar aos céus a proteção de todos os santos, anjos e arcanjos; Kelling usou da seguinte estratégia: dissera a Muatilefu que eles eram amigos do "rei do Cuanhama, que era neste momento o senhor absoluto de todo o Ovampo e de quem o chefe Muatilefu não era mais do que um simples

36 Boletim Geral das Colônias. Vol. III, n.19.Portugal:Agência Geral das colônias, 1927, p143.

37 Boletim Geral das Colônias. Vol. III,n.19. Portugal: Agência Geral das Colônias, 1927, p.144. 
vassalo. Mostrei-lhe que incorreria no desagrado do seu real amo e senhor se fizesse o menor mal à missão" ${ }^{\prime 3}$. O blefe surtiu efeito, Muatilefu retirou-se com seus guerreiros.

Era preciso procurar Mandume e negociar um acordo com o mesmo, até porque haviam prisioneiros em seu poder: dois brancos, além de 50 ganguelas cristianizados. Kelling atrelou os bois ao carro e partiu para a árdua tarefa de negociar com Mandume. O relatório descreve toda a trajetória que fizera, dia-a-dia, descrevendo a geografia da região, os percalços tais como o mal tempo, os costumes e a organização social daquela sociedade, uma ótima fonte para os estudos etnográficos. No dia nove de janeiro estavam frente a Mandume.

Transcreveremos a descrição para se ter uma ideia da organização daquele reinado. Não podemos esquecer que é um olhar filtrado pelas lentes de um missionário europeu, com a tarefa de construir uma relação de amizade, tendo em vista os acontecimentos recentes, sobretudo em virtude da presença das expedições militares lusas naquela região. Estamos querendo dizer que é uma representação que precisa ser relativizada em função do contexto em que foi elaborada. Vejamos o que nos diz Kelling:

[...] Mal estávamos instalados no novo lugar, quando às 9 horas aparece o cortejo real, a cavalo e seguido de inumeráveis mancebos e uma verdadeira matilha de cães.

Entre todos sobressai o monarca, montado nem soberbo cavalo branco e trajando roupas pretas, à européia. Logo atrás vinham 30 ministros, igualmente montados e vestidos à européia, em seguida 100 mancebos e 20 anos, com espingardas Kropatscheck. Ficam todos a certa distância enquanto vou ao encontro de sua majestade e só o primeiro ministro é que o acompanha até à entrada até à entrada da minha barraca.

Acho-me afinal em frente de Mandume, esse déspota temido dos pretos num raio de 20 dias, o incendiário da nossa missão, o terror dos brancos e o pesadelo do governo. Esperava ver um bandido terrível, de olhar sanguíneo,movimentos nervosos, aspecto feroz, e, em vez disso, tenho diante de mim um rapaz novo de 24 a 25 anos apenas, de uma estatura imponente, bastante nutrido, cara imberbe, apresentando uma leve cicatriz no olho esquerdo. Estende-me cortesmente a mão e responde sem acanhamento ao meu cumprimento. Desconfiado a princípio, expande-se como que por encanto, ao ver os presentes que lhe ofereço. O que maior prazer lhe causou foi uma caixa de ' congnac' e o vinho Porto; mas, diz:' gostaria também de champagne e de cerveja'. Deitei-lhe um pouco de vinho e brindou à minha saúde em português e alemão;mostrando que preferia os alemães aos portugueses,visto ter sido educado numa missão alemã protestante[...]"39.

A surpresa de padre Kelling com as atitudes e comportamento do rei e os componentes

38 Idem., p. 145

39 Boletim Geral das Colônias. Vol. I II, n.19. Portugal: Agência Geral das Colônias, 1927, p.157-158. 
de seu séquito ficam evidentes na adjetivação: esperava uma pessoa com aspecto de bandido, sanguinário, de movimentos nervosos, feroz... E encontrou um rei à europeia, segundo sua expressão. A realeza africana, como a descrição de Kelling, havia se reiventado à moda europeia, para usar uma expressão Hobsbawm e Ranger ${ }^{40}$. Em seguida ele justifica as razões de tão grande europeização: fora educado na missão protestante alemã. Mas esqueceu de dizer que as armas que utilizavam, as espingardas kropatchek foram desenvolvidas para as Forças Armadas Portuguesas, pelo general austro-húngaro Alfred Von Kropatschek ${ }^{41}$, tornando a espingarda padrão do exército português no período compreendido entre 1886 e 1904.

A descrição de Kelling nos lembra a de outros viajantes europeus que estiveram em África no século XIX, tal como Richard Francis Burton, Antônio Pacheco dentre outros. Era o olhar etnocêntrico do estrangeiro sobre o nativo, o bárbaro, 'indígena', do qual só se esperava ações correlatas aos seus 'estado natural'; daí a surpresa ao encontrar africanos à europeia, que, ao nosso ver, era fruto da presença europeia em África, seja de caráter comercial, militar, religiosa ou 'filântrópica'. E mais, o próprio kelling, levou presentes que não se limitaram à Biblia Sagrada, ou qualquer outro objeto sagrado que pudesse corroborar seu 'métier'; muito pelo contrário, os presentes eram de caráter profano, que podia inclusive corromper a moral e os bons costumes, discurso tão caro aos missionários da época.

O missionário só faltou dizer que Mandume era um verdadeiro 'gentleman', mas deu a entender quando mencionou seus gestos ao brindar à saúde do visitante, o gosto pelas bebidas finas, o falar português e inglês... E mais ao questionar o fato de o missionário estar usando a bandeira do Império português naquele que por certo era o seu. Vejamos o diálogo que se travou acerca deste assunto:

[...] Como no meu carro visse hasteada a bandeira portuguesa, pediu-me que a arreasse. Respondi-lhe que assim como os protestantes da missão dele, onde quer estivessem, mesmo em território português, faziam propaganda alemã, também nós, em território português defendíamos os interesses de Portugal. Além disso, que ele bem sabia que católico e português nestas terras era a mesma coisa. Concordou e deixou passar[... $]^{42}$.

Quanto as negociações acerca dos ataques e perseguições às missões, Mandume 'desconversou' dizendo que eram os ganguelas que convidavam os cuanhamas e que ele nunca dera ordens para atacar as missões, e que era impossível saber o que acontecia por lá. E concluiu,

40 Estamos nos referindo à obra: HOBSBAWM, Eric e RANGER,Terence (Orgs.). A Invenção Das Tradições. Rio de Janeiro: Paz E Terra,1984. Sobretudo o capítulo VI: A Invenção Da tradição Na África Colonial.

41 Sobre este assunto. pt.wikipedia.org/wiki/kropatschek_Portuguesa

42 Boletim Geral das Colônias. Vol. III,n.19.Portugal: Agência Geral das Colônias, 1927, p.158. 
segundo o relato do missionário por culpar o próprio governo português dizendo que

[...]Se o Muene Putu(governo de Portugal) houvesse, uma só vez que fosse ,dado uma boa trepa(lição) nos cuanhamas já estes La não voltariam tão facilmente. Mas parece que os brancos têm medo dos cuanhamas, assim como os alemães dos herreros. É isso que lhes dá coragem[... $]^{43}$.

O padre Kelling, talvez meio desconcertado com a astúcia de Mandume, mas sem se deixar mostrar surpreso, retrucou dizendo que se houvesse uma expedição convenientemente preparada, os cuanhamas não resistiram, mesmo sendo destemidos e, valentes; ao que Mandume olhou para o padre e sorriu.

kelling ainda insistiu, interrogando como é que Mandume com sua autoridade não impedia as guerras, ou ao menos castigasse exemplarmente os responsáveis por ela. Eis que a resposta foi:

[...] Fixou-me com um sorriso escarninho e reflexionou: 'impedi-los?! Castigar os meus cabos de guerra?! Mas então os brancos não sabem que é esse o meu ganha-pão, pois é delas que tiro aquilo de que preciso para pagar a minha gente?!'

Soube nessa ocasião (acrescenta o padre) que ele exigia, de cada vez, metade dos despojos que lhe servem para as despesas de estado e para satisfazer o soldo aos seus soldados. Para o cuanhama o roubo, o assalto, a pilhagem é um ofício muito lucrativo. Tanto pior para os que se deixam apanhar $[\ldots]^{44}$.

A conclusão de Kelling é que eles eram mesmo de má índole, e faziam da guerra um meio de sobrevivência. Não se deu conta que este tipo de guerra que se fazia com as espingardas kropatchek, era uma guerra à europeia, que antes da chegada dos colonizadores ela não existia. Não via nestas ações uma forma de resistência a presença dos estrangeiros, quer comerciantes, missionários, expedições militares ou filantrópicas; que na maioria das vezes não davam alternativas aos colonizados; apenas justificavam em nome da religião, da civilização e do progresso da sociedade humana.

Mas a conversa com Mandume não havia chegado ao fim, faltava ainda resgatar os prisioneiros brancos. Segundo o missionário foi aí que a 'conversa azedou', pois que Mandume "mostrou tão grande contrariedade que lhe vi de repente estampar-lhe no rosto, que julguei haver prejudicado o resto que já tinha obtido" ${ }^{\prime 4}$. Foi então que o missionário propôs trocar os prisioneiros

43 Idem.,p.158-159.

44 Idem., Ibide.,p. 159.

45 O Soba teria garantido ao missionário que puniria os que haviam surrado e roubado o padre Leguennec em junho do ano anterior, 1914,conforme lhe havia narrado o próprio Kelling numa longa conversa, como se depreende da 
por duas caixas de Champagne por cada um e a reposta foi a seguinte:

[...] Para resgatar prisioneiros negros,me respondeu ele, pode-se muito bem oferecer 'Champagne' ou 'congnac', e eu não direi que não; mas para resgatar soldados de Muene Putu... só espingarda finas e cartuchame.

Ofereci-me para servir de medianeiro entre ele e o governo. Nem me deixou continuar:

- Vieste aqui como missionário, ou como agente de Muene Putu?[...]"46.

Quando interrogado se podiam reconstruir a antiga missão, Mandume respondeu que não, pois que a missão trazia a ocupação portuguesa, disse mais, já havia uma missão na regão do Evale e isso bastaria. Foi o suficiente para o missionário concluir que Mandume era amigo dos alemães.

Terminada a ' negociação’ por aquele dia, o soba mandou oferecer ao missionário um grande boi,ao que o missionário denominou de ' um amplo gesto diplomático'.O soba não se fez presente para se despedir, ao que kelling concluiu que poderia ter sido pelo excesso de conhaque que havia tomado, ou devido aos pedidos que lhe teriam aborrecido.

Antes de retornar para seus 'aposentos', kelling teve a oportunidade de encontrar com Raimundo, um ex-aluno da missão, que estava á serviço do soba. Este lhe confidenciara que havia influência de um ministro da missão alemã que havia persuadido ao soba não receber o missionário católico, pois este não passava de um espião do governo português. $\mathrm{O}$ ex-aluno havia dito ainda que Mandume havia prometido entregar os prisioneiros brancos aos alemães. Disse mais o ex-aluno ao ex-mestre, que

[...] O rei do Cuanhama tem 330 ministros, sendo 300 espalhados pela terra e os outros 30 ao lado de si. Tem uma guarda pessoal composta de 100 soldados, escolhidos entre os ais esbeltos mancebos dos seus estados. Cada soldado tem uma espingarda 'Kropatschek' e os ministros ' Martiny' ou ' Mauser'.

Ao seu serviço particular traz Mandume 200 moços e 100 raparigas. Não é casado. Toda esta gente é de uma dedicação inimaginável, quando trata do seu senhor, que é para eles como que o omnipotente [...]"47.

Não comentaremos a descrição que Raimundo fez da corte de Mandume ao missionário, apenas acrescentamos que são os escritos feitos a partir de um religioso católico, que tinha como objetivo expandir a missão católica em terras africanas, num contexto de guerra mundial

página 160 e 161 deste Boletim que analisamos

46 Idem., Ibidem.,p.161.

47 Idem., Ibidem., p. 162-163. 
e de disputa com as missões protestantes. Portanto estes escritos têm um lugar social e é a parti dele que devemos fazer nossas análises.

O encontro com Raimundo, ex-aluno da missão católica, permitiu a kelling saber mais sobre Mandume, a corte e os prisioneiros. Estava determinado a não abandoná-los como escreveu em seu relatório:

[...] Aproveitei a vinda ao meu acampamento do Raimundo, - aquele cristão de quem falei, - interroguei-o com toda precaução e dele vim saber o seguinte: na imbala já se não encontrava senão o sargento Reis; o outro banco, que era um cabo, havia sido entregue à missão alemã do Cuanhama, e os missionários, por seu turno, tinham-no feito marchar para uma missão, igualmente alemã, que se achava em Ondonga. Soube que mais tarde esse cabo, após tormentos indescritíveis, fora solto e consta-me que se encontra presentemente em Portugal[...]"48.

Raimundo passou a ser de confiança de Kelling, afinal ele havia sido educado nas missões. Era também um dos homens de confiança de Mandume, assim não fosse, não ocuparia a função em que ocupava, aliás, função almejada por muitos, conforme explicação do mesmo Raimundo ao missionário ${ }^{49}$.Tanto Mandume quanto Kelling estavam certos da fidelidade de Raimnundo. Kelling confira tanto que

[...] Depois de muito refletir, tomei uma resolução arriscada: corto do meu caderno uma folha, escrevo um bilhetezinho, que entrego ao Raimundo, o qual me promete que embora vendo a dificuldade da empresa e o perigo a que se expõe, fará de modo que ainda nesse dia o meu bilhete chegue às mãos do branco $[\ldots]^{\prime \prime 50}$.

O bilhete, segundo o missionário, caíra em mãos de um sentinela que tomava conta do preso. Este sentinela, semelhante a Raimundo fora educado numa missão católica, em Huila. Sorte! Este respondeu ao missionário, dizendo que o preso estava bem 'guardado', que seria impossível sua fuga. Aconselhou-o fosse embora enquanto era tempo, pois se Mandume suspeitasse, seria o seu fim.

Com podemos notar, entre os homens de confiança de Mandume havia mais que um educado nas missões católicas, que segundo Kelling, Mandume tanto perseguia. Quais as possíveis razões do rei escolher tais sujeitos? Por eles conhecerem a dinâmica das missões e poderem ser confidentes do rei? Por possuírem o domínio da língua do colonizador? Acreditamos que estes possam ser alguns dos motivos e outros que desconhecemos no momento. O certo é que tanto do

48 Boletim Geral das Colônias.Vol. III., n.20.Portugal: Agência Geral das Colônias, 1927,p.59

49 Quando descrevera a corte de Mandume, Raimundo afirmara que "[...] A maior honra que pode ter um rapaz novo é ser admitido entres estes privilegiados. É igualmente a maior ambição que pode nutrir um velho: ter um filho na corte! [...]” In. Boletim Geral das Colônias. Vol. III, n.19. Portugal: Agência Geral das Colônias, 1927, p.163.

50 Boletim Geral das Colônias.Vol. III.,n.20, Portugal: Agência Geral das Colônias, 1927, p.59. 
lado dos missionários quanto do lado da corte, comportamentos ambíguos que poderiam ser decisivos para qualquer uma das partes.

Kelling disse ter ficado admirado que um negro dali pudesse ler e escrever, sua ideia de África não diferia da então vigente na Europa, apesar de todo o empreendimento 'civilizatório' que eles próprios aplicavam no continente. As ideias acerca de África ${ }^{51}$ sobrepunha a África real, como acontece ainda nos dias atuais como podemos constatar cotidianamente em depoimentos, debates e representações diversas sobre o continente no ocidente.

O missionário ao retomar suas atividades comunicou ao governador da Huíla que Mandume pedia armas finas pelo resgate do sargento, e que soubera mais tarde que o sargento fora morto por Mandume, quando as expedições lusas adentraram a região à caça do soba, que para os portugueses já havia extrapolado as medidas...

Ao retornar para a missão, o missionário descreve a destruição que se encontravam muitas obras construídas por eles e que Muatilefeu mandara destruir: “onde, há apenas um mês, tudo era vida, tudo movimento, mal distingo 4 ou 5 negros que no rescaldo buscam e rebuscam a ver se encontram ainda alguma coisa" ${ }^{, 52}$. Mais adiante encontra os pretos seguem atrás de um grupo "à europeia", trajados com as roupas dos soldados que estavam ou presos ou mortos em virtude do embate ocorrido:

[...] A pouco e pouco vão-se chegando os pretos, seguem atrás de nós. Vejo um vestido com capote de sargento, outro com umas calças de oficial; este traz na cabeça o chapéu colonial, de que se servem os soldados, aquele cobriu o tronco com um casado branco, que contradiz com a cor da sua pele $[\ldots]^{53}$.

Kelling e seus acompanhantes sentiram-se ameaçados com os pretos que os rodeavam, sobretudo quando ouviram, segundo ele, "palavras pouco próprias para lhe infundir coragem", e reproduziu o que ouvira de um dos negros "à europeia” “[...] Então ainda brancos em nossa terra?! Nós que os expulsamos, que os matamos, havíamos de deixar passar este? Isso nunca. Não se há de gabar de ter atravessado a nossa terra [...]" $]^{\prime 54}$. Não houve incidente maior além das ameaças. Mas é bom lembrar que estas denotavam a autoridade dos nativos sobre a terra, os brancos eram intrusos.

$\mathrm{O}$ padre kelling descreve em seguida, a chegada da expedição que combateria Mandume e o venceria em Mongua. Mas o que nos chama atenção é uma das versões da morte de

51 Sobre esta questão. Ver. MUDIMBE, V.Y. The Idea Of Africa.Indiana: Indiana University Press, 1994.

52 Boletim Geral da Colônias, Vol. III.,n.20, Portugal: Agência Geral das Colônias, 1927,p.67.

53 Idem., p. 67

54 Idem., Ibidem.,p. 67. 
Mondume a partir da tradição dos cuanhamas.Versão que ilustra a resistência dos 'indígenas' à presença do colonizador:

[...]Conta agora aqui a versão inglesa que Mandume não fora ferido na articulação,mas alvejado de maneira tal que ficara logo ali. Pelo contrário,os cuanhamas, que seguiam o soba, afirmam que ele apenas perdeu algum sangue pela ferida e fora levado pelos seus. Dizem mais que vendo-se naquele estado, num relance de olhos mediu a sua pouca ou nenhuma possibilidade de salvação e virando-se para os sobrinhos, os filhos do falecido soba Eyulu, de quem já falamos, lhe perguntou se 'queriam ser muleques dos brancos'. Como eles dissessem que antes queriam morrer, o soba, levando a espingarda à cara, prostrou-os com dois tiros e,virando em seguida a arma contra si mesmo, fez saltar os miolos[...]"55

A versão do colonizador e a versão do colonizado, duas representações que reflete o lugar social de cada grupo que a narra. Um combate pela história, para usar uma expressão de Lucien Febvre. Combate este que vem sendo travado pelos pesquisadores africanos e da diáspora desde a década de cinqüenta, sobretudo, visando descontruir a ideia de que na África não havia história, tão veiculado no ocidente ao longo do século XIX, tendo inclusive o filósofo Hegel ${ }^{56}$ como um dos seus divulgadores.

A segunda versão, a dos colonizados, aponta para a dignidade dos africanos, qual seja, antes morrer do que submeter-se. Versões semelhantes encontramos na diáspora africana, como por exemplo, a versão da morte de Zumbi do Palmares no século XVII. Ele teria pulado de um precipício quando viu que seria tragado pelas forças do governo colonial. Versão que ganhou notoriedade com a emergência dos movimentos sociais negros a partir do final da década de 1970.

\section{Referências:}

Boletins.

Boletim Geral das Colônias, Vol. I, n.02. Portugal: Agência Geral das Colônias,1925.

Boletim Geral das Colônias, Vol. II, n.18. Portugal: Agência Geral das Colônias, 1926.

Boletim Geral das Colônias, Vol.III, ns.19 e 20. Portugal: Agência Geral das Colônias, 1927.

Cadernos Coloniais:

GUARDADO, A. A. da Silva. Cadernos Coloniais, n.34. O Massacre dos dragões do Conde de

55 Idem. Ibidem., p.76.

56 “[...] A África está sempre fechada no contato com o resto do mundo, é um Eldorado recolhido em si mesmo, é o país criança, envolvido na escuridão da noite, aquém da luz da história consciente [...]Nesta parte principal da África não pode haver história[..]" .HEGEL, George W.F. Filosofia de La historia universal.Madri: revista de Occidente, 1928. Apud. HERNANDEZ, Leila. A África Na Sala De Aula. São Paulo: Selo Negro, 2008,3ª . Ed.,p.20. 
Almoster Lisboa: Editorial Cosmos, 1939.

CONTREIRAS JÚNIOR, Manuel Francisco. Cadernos Coloniais, n.44 (O Massacre Do Cunene ). Lisboa: Editorial Cosmos, 1937.

SOUZA, João Francisco de. Infantaria 17 em África. Cadernos Coloniais, n. 57. Lisboa: Editorial Cosmos, 1939.

Sites eletrônicos:

http://memoria-africa.ua.pt/introduction/tabid/83/language/pt-PT/Default.aspx

pt.wikipedia.org/wiki/kropatschek_Portuguesa

Livros:

ACHABE, Chinua. O Mundo Se Despedaça. São Paulo: Ática, 1983.

CLASTRES, Pierre(Org.). Guerra, Religião, Poder. Lisboa: Ed. 70,1977.

DE CERTEAU, Michel. A Invenção Do Cotidiano. Vols. I e II. Petrópolis: Vozes,1994.

HERNANDEZ, Leila. A África Na Sala De Aula. São Paulo: Selo Negro, 2008,3ª . Ed.

HOBSBAWM,Eric e RANGER,Terence(Orgs.). A Invenção Das Tradições. Rio de Janeiro: Paz E Terra, 1984.

LOPES,Nei. Enciclopédia Brasileira Da diáspora Africana. São Paulo: Selo Negro, 2004.

LOPES,Nei. Novo Dicionário Banto Do Brasil. Rio de Janeiro: Ed.Pallas, 2003.

M'BOKOLO, Elikia. África Negra: História E Civilizações. Tomo I.Salvador: Edufba/ SP: Casa das Áfricas,2009,p.180.

MUDIMBE, V.Y. The Idea Of Africa. Indiana: Indiana University Press, 1994.

KI-ZERBO,J.(org) História geral Da África Vol. I - Metodologia e pré-história da África.Paris: Unesco/Brasília:Ministério da Educação, 2010, 2ª . Ed. rev.

SOUZA, Laura de Mello e. O Diabo E A Terra De Santa Cruz: Feitiçaria e religiosidade popular no Brasil Colonial. SP: Companhia das Letras, 1986.

Recebido em 28/03/2016 - Aprovado em 25/08/2016 